\title{
Do Space Requirement Applicable in Private Preschools?
}

\author{
Naziah Muhamad Salleh1,a , Nuzaihan Aras Agus Salim¹, Syahrul Nizam Kamaruzzaman² and Norhayati Mahyuddin² \\ ${ }^{1}$ School of Housing Building \& Planning, University Science Malaysia, 11800 Penang, Malaysia \\ ${ }^{2}$ Faculty of Built Environment, University of Malaya, 50603 Kuala Lumpur, Malaysia
}

\begin{abstract}
Working or studying in a comfortable environment enhances not only well-being, but also satisfaction and therefore increase the productivity and learning. The numbers of private preschool in Malaysia boost every year. Frequently they operate in premises that have been fully refurbished. This has invited the questions on the building capability and space condition to provide a good environment to the children during the learning activities. Most of the building was refurbished to enhance it applicability as a school. Yet, these adaptive-reused buildings are doubtful. This research focused to identify the characteristics of the buildings' physical and condition as well as the scenario of refurbished private preschool in accordance with the standard. Observation particularly on space and pupils density either it is reckoning with the authorities' requirements. Most of the building was refurbished to enhance it applicability as a school. The data obtained from the observation and staff's interview to 237 preschool ( 771 classrooms). The data revealed in most of preschools, the occupants in the classrooms were over the limit regulating by the authority. The data obtained was analyzed to become a reference and benchmark to the authorities to prepare the private preschool's applications.
\end{abstract}

Keywords: Refurbishment, Preschool, Occupants Perception, Space Requirement

\section{Introduction}

Malaysia has experienced high economic growth accompanied by rapid awareness of education. Early education becomes one of the main focuses in the Malaysian Educational Development Master Plan 2006-2010, by providing the preschool classes in the government schools [1]. By 2020, $100 \%$ of children oblige to enroll preschool before they enter the primary education in national schools [2]. It is highlighted to strengthen the nation's human resource development, facilities and the education participation rate. The numbers have improved significantly with the increasing participation made at the preschool.

Preschool or kindergarten (in German, literally means "children's garden") is a form of education for

young children which serves a transition from home to the commencement of more formal schooling [3]. Children are taught to develop basic skills through creative playing and social interaction. In most countries, kindergarten is part of the preschool system. Children usually attend preschool anytime between the ages of two to six years, depending on the local custom [4]. In

Malaysia, children usually attend preschool any time between the ages of four to six in private and government school [1].

Research done by [5], has elicited that the coverage for preschool education has improved dramatically over the last decade by one-half, from 17 percent of 4-6 years in 1981 to 41.5 percent in 1995. Also, the 1996 Malaysia Education Act and Malaysia Education Blueprint in 2013 [6] has amended to make the preschool compulsory. This progress has encouraged more private preschool centres to set up where it involved various types of the refurbished building in urban areas. According to [7], terrace houses become the most common property to be converted into preschools which would consist of classrooms that accommodate 20 to 30 pupils at a time.

\footnotetext{
a Corresponding author: naziahmsalleh@usm.my
} 
The previous litigations and studies suggested adequate learning environment for these children. Referring to [8], the occupant in a classroom requires at least $2 \mathrm{~m}^{2}$ per person, which implies a requirement of $40 \mathrm{~m}^{2}$ to accommodate twenty pupils in a space. These to ensure the classrooms are wellventilated [9. 10]

Hence, in school environments perspectives, there is a relation to the implications of the spatial volume, for example, found that differentiation in ceiling height was related to higher levels of cooperative behavior among preschool children. On the issue of space perception, [11] reported that if some space is constructed and equipped in the right way, the development of a child's increased abilities is supported, and this allowed the child's capacities to be confirmed by the child. Pertaining to playroom arrangement, the type of furniture arrangement did not change the joint use of play areas and the social interactions for the peers whose relationships were weak [12]. In contrast, for children showing an emerging relationship, the playroom arrangement affected the quantity and the quality of their social interactions.

The combination of shared and personal spaces for student and teacher, can help to nurture an orderly and serious academic atmosphere [13]. This is support by [13] whereas the open plan classroom with effective activity area makes the teaching situation flexible and share space is an extension of the classroom's activities. Non-appropriate behaviors were observed in the poorly defined classrooms where the classrooms are entirely in impropriate layout and lower floor area. While, it seemed that a well-defined classroom would inhibit more appropriate behaviors [15]. Class size is an important design and drives a host of costly facility-related issues that are part and parcel of the school building's planning, design, construction, cost, maintenance and operation [16]. It becomes a big factor in determining the number of teachers needed and hence, it affects the education outcomes.

Good space management will stem from business trends that encourage work-style, such as knowledge-sharing, collaborative work, increased mobility and working productivity. These key influencing factors need to perfectly synchronizing with best work practice to achieve success and it has become the major factor influencing workplace design. The main consideration in space management is to acknowledge the need of the occupants rather than the building and physical space in order to give the positive impact to the organization as well as in school environment predictions.

Thus, this paper resumes to identify the characteristics of the buildings' physical and condition as well as the scenario of refurbished private preschool in accordance with the authorities' standard and regulation.

\section{Materials and Methods}

The school grounds' walk-through form was used by the research team to characterise the materials and condition of each school in general terms. Items characterised included a description of the school grounds, indoor environment and kitchen. Some specific information was gathered, comprising the building age, number of stories, recent or ongoing renovations, presence and number of portable buildings, common area finish materials, lighting, barrier mats, cleanliness, and maintenance closet chemical storage and ventilation strategies.

The study was conducted in refurbished private kindergarten or preschool buildings which have been registered with the Ministry of Education. All 1000 preschools around Malaysia were randomly selected from the approved list of Private Education Sector, Ministry of Education, Malaysia. First, a letter of permission to run the survey sent out earlier. As a result, total 285 owners replied to the letter. Out of them, only 237 preschools (771 classrooms) have granted the permission to conduct the research in their premises. The observation process took about fifteen to thirty minutes to be completed.

The descriptive analysis on location, the nearest main road, type of building, building and classroom floor area, ventilation strategies, maintenance and cleaning, numbers of occupants (teachers and pupils in the classrooms), type of operation, operating hour, and renovation purposes were applied. Since the data obtained were non-parametric, the Chi-square test has done for independence to identify the most variables related to the requirement of number of pupil/occupant in the classrooms.

In this section, the observations were analysed via different methods. The descriptive statistical parameters (i.e. arithmetic means, standard deviations, maxima and minima) were used to present the data. Meanwhile, non-parametric test Chi-square independent test applied to evaluate the variable related to the requirement of number of pupil/occupant in the classrooms. The number of valid occupants (pupils and teacher) per classroom verified by the formula specified by Malaysia Ministry of Malaysia:The actual or valid classroom, then subtracted from the actual number of occupants in the classroom.

\section{Number of student $=[($ Length $\mathrm{x}$ Width $) \div 15]$ $-1$ \\ *Leneth and width must be in $\mathrm{ft}$}

\section{Regulation status $=$ Valid number of occupants - Actual number of pupils per classroom}

Negative (-ve) result determined that the number of the occupants in the classrooms is not complying with the MOE guidelines, while the positive $(+v e)$ results indicated the number of pupils are in compliance with the guidelines. 


\section{Results and discussions}

Figure 1 illustrates the proportion of premises in this study that refurbished as preschools, with majority of 237 preschools previously were the terrace houses. With regards to the lack of technical knowledge, most of the renovation and refurbishment work was conducted using unsuitable and inconsistent techniques, which gave poor results on the interiors as well as exteriors. Thus, it will affect the children and teacher sensitivity towards the environment of the building.

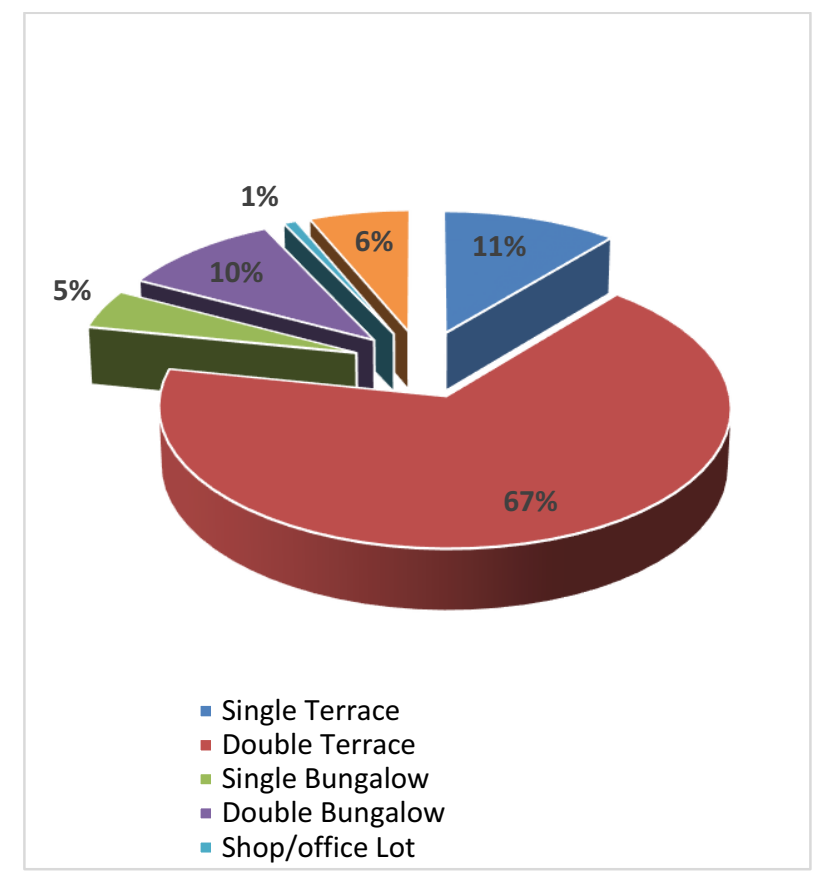

Figure 1. Premises to be refurbished as preschools in this research

\subsection{Building characteristics}

This section discusses the findings of characteristics and physical of 237 preschools buildings. The discussions are encompassing the descriptive analyses of building characteristic, type of refurbishment, function to commence the refurbishment and the accomplished numbers of pupils with MOE requirements.

\subsection{Descriptive analysis}

The overall descriptive results of building types, ownership, age of the building, activity performs in the preschools, age of the pupil, location of the building to the nearest road traffics, ventilation strategies, building maintenance and services, absence of any contaminants agents are presented in Table 1.
Table 1. Descriptive Analysis of Preschool Building

\begin{tabular}{|c|c|c|}
\hline $\begin{array}{l}\text { Categorical } \\
\text { Variables }\end{array}$ & Description & $\%$ \\
\hline Building types & $\begin{array}{l}\text { Single Terrace } \\
\text { Double Terrace } \\
\text { Single Bungalow } \\
\text { Double Bungalow } \\
\text { Shop/office Lot } \\
\text { Others }\end{array}$ & $\begin{array}{r}11.0 \\
67.1 \\
4.6 \\
10.1 \\
0.8 \\
6.3\end{array}$ \\
\hline $\begin{array}{l}\text { Ownerships of } \\
\text { the Building }\end{array}$ & $\begin{array}{l}\text { Own } \\
\text { Rental }\end{array}$ & $\begin{array}{l}34.2 \\
65.8\end{array}$ \\
\hline $\begin{array}{l}\text { Age of the } \\
\text { Building }\end{array}$ & $\begin{array}{l}<5 \\
5-10 \\
\mathbf{1 0 - 1 5} \\
15-20 \\
20-30 \\
>30\end{array}$ & $\begin{array}{r}5.9 \\
28.7 \\
33.3 \\
14.3 \\
16.0 \\
1.7\end{array}$ \\
\hline $\begin{array}{l}\text { Recent } \\
\text { Renovation }\end{array}$ & Yes & 54.4 \\
\hline Programme & $\begin{array}{l}\text { Preschool only } \\
\text { Daycare only } \\
\text { Preschool+Daycare } \\
\text { Preschool+Tuition } \\
\text { Preschool+Daycare+Tuition }\end{array}$ & $\begin{array}{r}\mathbf{5 8 . 2} \\
3.4 \\
30.8 \\
3.4 \\
4.2\end{array}$ \\
\hline Age of Pupils & $\begin{array}{l}>4 \text { years old } \\
4-6 \\
5-6 \\
>6 \\
\text { others }\end{array}$ & $\begin{array}{r}1.7 \\
69.2 \\
1.3 \\
20.7 \\
7.2\end{array}$ \\
\hline Traffic Type & $\begin{array}{l}\text { Small local street } \\
\text { Medium local street } \\
\text { large local street } \\
\text { Expressway }\end{array}$ & $\begin{array}{r}12.7 \\
\mathbf{6 5 . 0} \\
16.0 \\
6.3\end{array}$ \\
\hline Traffic Density & $\begin{array}{l}\text { Low } \\
\text { Medium } \\
\text { Heavy }\end{array}$ & $\begin{array}{l}30.4 \\
\mathbf{5 4 . 9} \\
14.8\end{array}$ \\
\hline $\begin{array}{l}\text { Ventilation } \\
\text { Type }\end{array}$ & $\begin{array}{l}\text { Dominantly natural } \\
\text { Dominantly air-condition } \\
\text { Both }\end{array}$ & $\begin{array}{l}33.8 \\
\mathbf{3 6 . 3} \\
29.9\end{array}$ \\
\hline \multicolumn{3}{|c|}{ Continued Table 1} \\
\hline $\begin{array}{l}\text { Categorical } \\
\text { Variables }\end{array}$ & Description & $\%$ \\
\hline Floor Surface & $\begin{array}{l}\text { Smooth } \\
\text { carpeted }\end{array}$ & $\begin{array}{l}\mathbf{8 4 . 8} \\
15.2\end{array}$ \\
\hline Curtain Types & $\begin{array}{l}\text { None } \\
\text { Blinds } \\
\text { Textiles }\end{array}$ & $\begin{array}{r}62.9 \\
7.6 \\
29.5\end{array}$ \\
\hline $\begin{array}{l}\text { Cooking } \\
\text { Activities }\end{array}$ & Yes & 70.9 \\
\hline Dampness & Yes & 52.3 \\
\hline Mould Growth & Yes & 54.0 \\
\hline
\end{tabular}




\begin{tabular}{|l|l|r|}
\hline Vermin Absent & Yes & 76.0 \\
\hline Soft Toys & Yes & 85.2 \\
\hline Floor Cleaning & Twice daily & 30.4 \\
& Daily & 69.6 \\
\hline Fan Cleaning & Twice weekly & 8.0 \\
& Weekly & 85.0 \\
& monthly & 26.5 \\
\hline Shelf Cleaning & Daily & 28.7 \\
& Weekly & 51.5 \\
& Twice a week & 19.8 \\
\hline Table Cleaning & Daily & 66.2 \\
& Twice a week & 28.7 \\
& Weekly & 5.1 \\
\hline Toilet Cleaning & Daily & 78.5 \\
& Twice a week & 19.8 \\
& Weekly & 1.7 \\
\hline Curtain & Weekly & 6.3 \\
Cleaning & Monthly & 46.4 \\
& Biannually & 26.6 \\
& Never & 20.7 \\
\hline
\end{tabular}

\subsection{Type of refurbishment}

Refurbishment of preschools varies depending on the owner's finances, vision and number of pupils. There might be major or minor refurbishment of the building. Table 2 shows the type of renovations that recently have been done on the 237 preschool building.

Though the repair works were the common renovation done at the preschool building. While the improvement of new building function is considered to be ranked as second for refurbished work among the preschool buildings. It basically initiates to give a comfortable space to the occupants.

Table 2. Type of refurbishment in refurbished private preschool

\begin{tabular}{|l|c|c|} 
& $\mathrm{N}$ & Percent \\
\hline Repairs on available building & $\mathbf{7 5}$ & $\mathbf{3 1 . 6}$ \\
Renovation and alteration & 38 & 16.0 \\
Improvement of function & 45 & 19.0 \\
Additional to structure of the & 21 & 8.9 \\
building & & \\
Retrofitting & 31 & 13.1 \\
Painting & 27 & 11.4 \\
Total & 237 & 100.0 \\
\hline
\end{tabular}

\subsection{Function of renovation}

Adopting from a survey by [17], an observation on the function of renovation of preschool building has been undertaken. Table 3 shows the function of renovation at preschool building. The preschools' owners deliberated the building space to accommodate the number of pupils. It is used to enhance the working environment and performance. The main concern for changing the function of any building is how to provide a sufficient space and place for tenants [18].

Table 3. Function of renovation at preschool building

\begin{tabular}{|l|r|r|}
\hline & N & Percentage \\
\hline Fictional arrange usable space & $\mathbf{6 5}$ & $\mathbf{2 7 . 4}$ \\
To add comfort to the building & $\mathbf{5 9}$ & $\mathbf{2 4 . 9}$ \\
Aesthetic to improve the appearance & 26 & 11.0 \\
of the building & & \\
Functional change of use & 22 & 9.3 \\
Change number of occupants & 13 & 5.5 \\
Improve market value & 18 & .8 \\
Reducing cost of maintenance & 32 & 7.6 \\
Legal change due to add health & & 13.5 \\
needs & 237 & 100.0 \\
\hline
\end{tabular}

\subsection{Classroom floor area vs number of pupils (space)}

Overall, a total of 711 classrooms of 237 preschools were observed with respect to the number of occupants in the classrooms and sufficient area provided. Table 4 indicates the mean classroom area at $15.51 \mathrm{~m}^{2}$ and the number of occupants in a classroom of the observed preschool is 16 people. It indicated the number of pupil and teacher in the classroom of any adaptive-reused classrooms at average as the given result.

Table 4. Classroom area $\left(\mathrm{m}^{2}\right)$ and existing number of occupants per classroom

\begin{tabular}{|l|r|r|r|r|r|}
\hline & N & \multicolumn{1}{|c|}{ Range } & Minimum & Maximum & \multicolumn{1}{c|}{ Mean } \\
\hline Classroom Fl Area $\left(\mathrm{m}^{2}\right)$ & 711 & 34.40 & 7.40 & 41.80 & 15.5054 \\
Numbers of occupants & 711 & 25 & 6 & 31 & 16.19 \\
\hline
\end{tabular}




\subsection{Accomplished number of occupants in a classroom with the regulation}

After adopting the formula, Figure 2 reveals the majority of the classrooms were not complying with the regulations of MOE. Whereas, only $8.9 \%$ or 63 classrooms met the available terms of regulations. The rest of the classrooms have greater occupants i.e., more than 15 people per classroom. Since the previous results indicated that the mean of the occupants per classroom was 16.19 , it is predictable that the most of the occupants of the classrooms were over the limit.

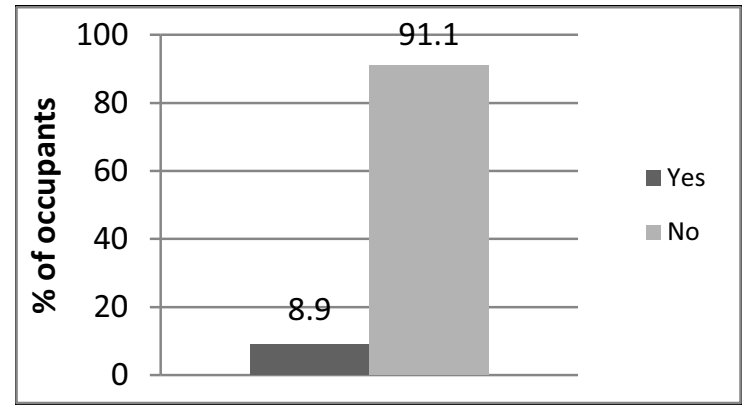

Figure 2. Percentage of preschool classrooms accomplished the MOE regulations

\subsection{Variable related to the requirement of pupils' density in the classrooms}

Previously, frequencies of accomplished occupants in the preschool's classrooms have been identified. In this section, the study has been focused on the factor which might relate to the numbers or requirement of the previous numbers in the classrooms, which is not in compliance with the MOE requirement.
The chi-square test [19] was used to test if sample of data came from a population with a specific distribution. In addition, the frequency of cases on this subject, possessing some quality, varies between levels of a given factor or among a combination of levels of two or more factors. The variables which were associated with the number of pupils/occupants that complied in the classroom were the building types, ownership of the building, ventilation strategy, classroom floor area, the recent renovation and function of renovation.

According to the observations provided in the Table 5 above, there is a significant relationship between ownership of the building $(\chi 2=5.552, \mathrm{~N}=711, \mathrm{p}<.05)$ and classroom floor area $(\chi 2=156.20, \mathrm{~N}=711, \mathrm{p}<.05)$ with the classroom, where the pupils' number complied with the MOE requirements. Whereas, building type, ventilation strategies, recently renovated building and function of renovation has no significant relationship with the MOE regulation.

Whilst, the previous double storey house premises ( $n=436$ classrooms) were the frequent condition. It indicated that the preschools were unable to comply with the number of pupils per classrooms as required by MOE. The other variables stated that most classes against the requirements were the classrooms operated in the rental premises ( $\mathrm{n}=435$ classrooms), airconditioned classrooms, classrooms with floor area 20$30 \mathrm{~m}^{2}(\mathrm{n}=648$ classrooms $)$, being renovated recently $(\mathrm{n}=$ 356 classrooms) and those renovated in order to arrange the space usage ( $\mathrm{n}=181$ classrooms).

Table 5. Variables Related to the Requirement of Number of Pupils in Classrooms

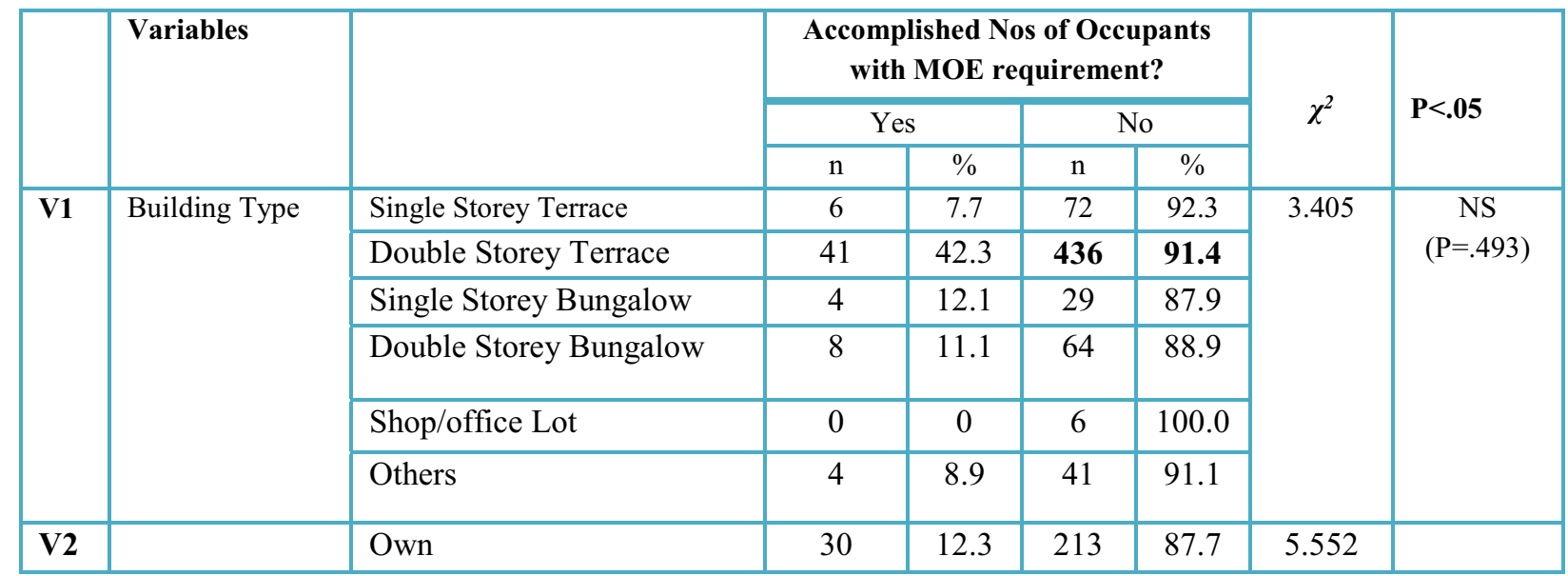




\begin{tabular}{|c|c|c|c|c|c|c|c|c|}
\hline & $\begin{array}{l}\text { Ownership of } \\
\text { Building }\end{array}$ & Rental & 33 & 7.1 & 435 & 92.9 & & $\begin{array}{c}\mathrm{S} \\
(\mathrm{P}=.018)\end{array}$ \\
\hline \multirow[t]{3}{*}{ V3 } & \multirow{3}{*}{$\begin{array}{l}\text { Ventilation } \\
\text { Strategy }\end{array}$} & Natural & 22 & 8.9 & 224 & 91.1 & \multirow[t]{3}{*}{0.172} & \multirow{3}{*}{$\begin{array}{c}\mathrm{NS} \\
(\mathrm{P}=.918\end{array}$} \\
\hline & & Air-Condition & 24 & 9.3 & 234 & 90.7 & & \\
\hline & & Both & 17 & 8.2 & 190 & 91.8 & & \\
\hline \multirow[t]{3}{*}{ V4 } & \multirow{3}{*}{$\begin{array}{l}\text { Classroom } \\
\text { Area }\end{array}$} & $<10 \mathrm{~m}^{2}$ & 7 & 9.5 & 67 & 90.5 & \multirow{3}{*}{$\begin{array}{c}156.21 \\
0\end{array}$} & \multirow{3}{*}{$\begin{array}{c}\mathrm{S} \\
(\mathrm{P}=.00)\end{array}$} \\
\hline & & $10-20 \mathrm{~m}^{2}$ & 13 & 2.6 & 484 & 97.4 & & \\
\hline & & $20-30 \mathrm{~m}^{2}$ & 63 & 8.9 & 648 & 91.1 & & \\
\hline \multirow[t]{2}{*}{ V5 } & \multirow{2}{*}{$\begin{array}{l}\text { Recent } \\
\text { Renovation }\end{array}$} & Yes & 31 & 8.0 & 356 & 92.0 & \multirow[t]{2}{*}{0.761} & \multirow{2}{*}{$\begin{array}{c}\mathrm{NS} \\
(\mathrm{P}=.383)\end{array}$} \\
\hline & & No & 32 & 9.9 & 292 & 90.1 & & \\
\hline \multirow[t]{8}{*}{ V6 } & \multirow[t]{8}{*}{$\begin{array}{l}\text { Function of } \\
\text { Renovation }\end{array}$} & $\begin{array}{l}\text { Fictional arrange usable } \\
\text { space }\end{array}$ & 14 & 7.2 & 181 & 92.87 & \multirow[t]{8}{*}{11.275} & \multirow[t]{8}{*}{$\begin{array}{c}\mathrm{NS} \\
(\mathrm{P}=.127)\end{array}$} \\
\hline & & To add comfort & 18 & 10.2 & 159 & 89.8 & & \\
\hline & & $\begin{array}{l}\text { Aesthetic improve } \\
\text { appearance }\end{array}$ & 5 & 6.4 & 74 & 93.6 & & \\
\hline & & Change of use & 11 & 16.7 & 55 & 83.3 & & \\
\hline & & $\begin{array}{l}\text { Change number of } \\
\text { occupant }\end{array}$ & 5 & 12.8 & 34 & 87.2 & & \\
\hline & & To Improve market value & 0 & 0 & 6 & 100 & & \\
\hline & & $\begin{array}{l}\text { Reducing cost of } \\
\text { maintenance }\end{array}$ & 1 & 1.9 & 53 & 98.1 & & \\
\hline & & $\begin{array}{l}\text { Legal change to add health } \\
\text { needs }\end{array}$ & 9 & 9.4 & 87 & 90.6 & & \\
\hline
\end{tabular}

\section{NS: Not significant at $\mathrm{p}>.05$}

\section{Conclusions}

The majority of the schools, discussed in the local and international studies, were exposed to the inadequate physical environment due to insufficient ventilation, maintenance activities, congested space, and presence of contamination sources through building materials, furnishings and equipment. The development of preschool in Malaysia has dominated radically in order to promote early education of the pupils in their adolescence age.

The observation and in-situ building investigations demonstrated in this research which is to identify the characteristics of the buildings' physical and condition as well as the scenario of private preschools' buildings. The private preschools have been operating in the refurbished buildings, previously used for the residential purpose. Surprisingly, after superimposing the collected data in the equation from the Malaysian Ministry of Education, for the appropriate capacity of pupils in the classroom, it has significantly concluded that the results of over $90 \%$

\section{S: Significant at $\mathrm{p}<.05$}

randomly selected classrooms were beyond the certain limit, which means that those classrooms were unable to cater for the appropriate number of children at a time. Preschool building conditions included a double story terrace, rental premises, air-conditioned classroom, classroom with floor area $20 \mathrm{~m}^{2}-30 \mathrm{~m}^{2}$ and recently renovated classrooms.

This study has provided the current situation in private preschools, which helped to identify the conflict during its operation as well as the effects of those conflicts on the pupils. The Ministry of Education should take into account the number of pupils occupying the classrooms before giving any approval to the preschool owners. Unfortunately, during the walk-in observations, over $90 \%$ of preschools' classrooms have exceeded the standard limit on number of pupils per classroom. This situation created problems for the children to learn due to the congested space, uncomfortableness, impaired concentration towards learning. If these environmental conditions persisted, the health symptoms of the children may get worse due to the inadequate ventilation and IAQ. Therefore, the inspection of the preschool operations should be done regularly. 
The data acquired in this study have indicated that the number of these adaptive classrooms has exceeded from 15 people per classrooms as gazetted by MOE. Yet, the mean area of 711 classrooms was signifying at $15.5 \mathrm{~m}^{2}$. According to [8], pupil requires at least $2 \mathrm{~m}^{2}$ per person, which suggests that the classroom could only accommodate an average of 7 pupils in a classroom.

\section{Acknowledgements}

The authors gratefully acknowledge the financial support of the Short Term Grant (2016) no. 304/PPBGN/6313274 established by the University Science Malaysia

\section{References}

1. Educational Planning and Research Division (2014). Malaysian Educational Statistics. Ministry of Education

2. [MOE] Ministry of Education. (2012). Preliminary report: Malaysia education blueprint 2013-2025. Retrieved on 11 September 2014, at http://www.moe.gov.my/userfiles/file/PPP/Preliminary -Blueprint-Eng.pdf.

3. J. R. Cryan, R, Sheehan, J. Wiechel, I. G. BandyHedden, I. G. Success outcomes of full-day kindergarten: more positive behavior and increased achievement in the years after. Early Childhood Research Quarterly, 7 (2), 187-203(1992)

4. N.L. Karweit, R.E. Alavin, N.A. Madden, Effective kindergarten programs and practices for students at risk of academic failure. Needham Heights, MA: Allyn and Bacon (1992)

5. [MOE] Ministry of Education, (2001), Education development Plan for Malaysia 2001-2010, retrieved on 11 April 2011, at: planipolis.iiep.unesco.org/upload/Malaysia/Malaysia\% 20development \%plan\%202001-2010summary.pdf.

6. [MOE] Ministry of Education. (2013). Preliminary report: Malaysia education blueprint 2013-2025. Retrieved on 11 September 2014, at http://www.moe.gov.my/userfiles/file/PPP/Preliminary -Blueprint-Eng.pdf.

7. Kuala Lumpur City Hall. Senarai tadika swasta sediaada di WPKL. Jabatan Perancang Bandar. Unpublished (2010)

8. Uniform Building by Law Act 1333. Laws of Malaysia, sixteenth ed., MDC Publisher, Kuala Lumpur (2009)

9. D. Shendell, A. Winer, R. Weker, S. Colombe. Evidence of inadequate ventilation in portable classrooms: results of pilot study in Los Angeles. Indoor Air, 14, $154-158$ (2004)

10. J.M. Daisey, W. J. Angell. A survey and critical review of the literature on indoor air quality, ventilation and health symptoms in schools. Lawrence Berkeley National Laboratory Report No. LBNL-41517 (1998)

11. D. Stankovic, J.Stojic, Psycho-developing needs of children and spatial features for children's stay. Architecture and Civil Engineering, 5(1), 71 - 75 (2007)
12. M.C. Lee, K.W. Mui, L.T. Wong, W.Y. Chan, E.W,M Lee, C.T. Cheung. Student learning performance and indoor environmental quality (IEQ) in air-conditioned university teaching rooms. Build Enviro ,49, 238-44 (2002)

13. C. Uline, M. Tschannen-Moran, The walls speak: The interplay of quality facilities, school climate, and student achievement. Journal of Educational Administration, 46(1), 55-73 (2008)

14. Y. Zhang, P. Barret, Findings from a Post-occupancy Evaluation in the UK Primary Schools Sector" in Facilities: Special Issue on Environment Behaviour. Facilities Journal, 28(14), 641-666 (2010)

15. M.Y. Abbas, M. Othman, Social behavior of pre-school children in relation to physical spatial definition. Procedia - Social and Behavioral Sciences, 5(0), 935941 (2010)

16. M. Schneider, Do school facilities Affect Academic Outcomes?, National Clearinghouse for Educational Facilities, Washington, DC. (2002). Retrieved 11 September 2012, from http://www.edfacilities.org/pubs/outcomes.pdf

17. I. Rahmat, V. B. Torrence, A.H. Ezanee, Refurbishment cycles and the management of refurbishment projects, UiTM Research Center, Shah Alam, Selangor, Malaysia (2003)

18. D.K.H. Chua, A. Tyagi, S. Ling, S.H. Bok Process Parameter-Interface Model for Design Management. Journal of Construction Engineering and Management, 129(6), 653-663 (2003)

19. G.W. Snedecor, W.G. Cochran, Statistical Methods, (8th Edition), Iowa State University Press (1989) 